\title{
KONTRIBUSI KONSENTRASI DAN MOTIVASI BELAJAR DENGAN KETERAMPILAN BOLAVOLI DASAR MAHASISWA
}

\author{
Oleh \\ Erianti ${ }^{1}$, Pitnawati ${ }^{2}$, Ali Asmi ${ }^{3}$, Ali Umar ${ }^{4}$ \\ Jurusan Pendidikan Olahraga, Fakultas IImu Keolahragaan \\ Universitas Negeri Padang
}

\begin{abstract}
Abstrak:Permasalahan konsentrasi dan motivasi belajar mahasiswa Jurusan Pendidikan Olahraga FIK UNP, merupakan faktor-faktor yang perlu diteliti. Penelitian ini untuk mengetahui kontribusi konsentrasi dan motivasi belajar terhadap keterampilan bolavoli dasar, sehingga diharapkan dengan diketahui kontribusi konsentrasi dan motivasi belajar terhadap keterampilan bolavoli dasar. Instrumen penelitian yang digunakan adalah angket skala Likert dan tes konsentrasi, serta tes untuk keterampilan bolavoli. Sedangkan analisis yang digunakan adalah analisis korelasi product moment dan korelasi ganda, serta dilanjutkan dengan melihat seberapa besar kontribusi konsentrasi dan motivasi belajar terhadap keterampilan bolavoli dasar mahasiswa Jurusan Pendidikan Olahraga Fakultas IImu Keolahragaan Universitas Negeri Padang.

Kata kunci: Konsentrasi, Motivasi Belajar, Bolavoli
\end{abstract}

\section{PENDAHULUAN}

Bolavoli dasar merupakan salah satu mata kuliah wajib yang harus diikuti oleh mahasiswa pada Jurusan Pendidikan Olahraga Fakultas IImu Keolahragaan Universitas Negeri Padang. Salah satu ciri khas dari lulusan Fakultas ini adalah mahasiswa memiliki berbagai keterampilan olahraga, diantaranya adalah keterampilan bolavoli dasar. Keterampilan bolavola dasar adalah kemampuan penguasaan teknik dasar bolavoli yang meliputi unsure servis, passing bawah dan passing atas. Artinya mahasiswa bisa lulus mata kuliah bolavoli dasar harus mengusai ketiga teknik dasar bolavoli tersebut.

Untuk bisa menguasai keterampilan bolavoli dasar, mahasiswa harus belajar dan berlatih secara benar dalam setiap tatap muka perkuliahan, serta belajar secara mandiri. Artinya mahasiwa akan belajar secara mandiri selain belajar pada tiap-tiap tatap muka, agar mahasiswa memperoleh hasil belajar dengan baik bolavoli dasar dengan nilai baik. Belajar merupakan suatu proses yang dilakukan oleh mahasiswa untuk memperoleh suatu perubahan tingkah laku yang baru secara keseluruhan, sebagai hasil dari pengalaman individu itu sendiri dalam interaksi dengan lingkungannya.

Untuk mendapatkan hasil belajar keterampilan bolavoli dasar dengan nilai baik, memang tidak mudah karena didukung oleh beberapa faktor antara lain yaitu kemampuan dosen dalam mengajar, kondisi fisik mahasiswa, sarana dan prasarana yang tersedia, 
metode dan media pembelajaran yang digunakan, motivasi belajar mahasiswa, konsentrasi mahasiswa dalam belajar, kesiapan mahasiswa dalam belajar, serta lingkungan belajar. Semua faktor ini dapat menimbulkan permasalahanpermasalahan yang terjadi dalam proses perkuliahan bolavoli dasar sehingga mahasiswa banyak yang rendah penguasaan teknik bolavoli dasar.

Berdasarkan di atas, maka pada kesempatan ini penulis ingin melakukan suatu penelitian tentang bagaimana keterampilan bolavoli dasar mahasiswa Jurusan Pendidikan Olahraga FIK UNP yang meliputi: servis bawah, passing bawah dan passing atas, yang mengambil matakuliah bolavoli dasar pada semester Juli-Desember tahun 2016. Kemudian dilanjutkan dengan faktor apakah yang menyebabkan masih banyak mahasiswa belum memiliki keterampilan bolavoli dasar.

\section{METODE}

Dalam penelitian ini yang akan menjadi peubah yang diamati/diukur yaitu konsentrasi, motivasi dan keterampilan teknik dasar mahasiswa Jurusan Pendidikan Olahraga Fakultas IImu Keolahragaan Universitas Negeri Padang yang berjumlah sebanyak 40 orang.

Model penelitian yang digunakan adalah penelitian korelasional, yaitu penelitian untuk mengetahui ada tidaknya hubungan antara dua variabel atau lebih dan dinyatakan dalam bentuk koefisien korelasi". Dengan demikian penelitian ini akan mengungkap seberapa besar hubungan konsentrasi dan motivasi belajar dengan keterampilan bolavoli dasar, selanjutnya dilanjutkan melihat seberapa besar sumbangan atau kontribusi konsentrasi dan motivasi belajar terhadap keterampilan bolavoli dasar.

peneliti menggunakan metode observasi, wawancara, qusioner dan tes yaitu tes konsentrasi dan tes keterampilan bolavoli dasar yang meliputi keterampilan teknik servis bawah, passing atas dan passing bawah.

\section{HASIL DAN PEMBAHASAN}

1 Konsentrasi

Konsentrasi secara umum merupakan suatu usaha pemusatan perhatian yang dilakukan secara sadar dan dengan sengaja dilakukan. Konsentrasi belajar diartikan adalah kemampuan untuk memusatkan pikiran terhadap aktifitas belajar. Proses ini dilakukan dengan pengambilan tes konsentrasi di dalam ruangan agar tidak banyak gangguan terhadap konsentrasi mahasiswa. Kemudian data dari tes konsentrasi dikorelasikan dengan data keterampilan bolavoli dasar yang diperoleh dari tes keterampilan bolavoli dasar. 
Distribusi Frekuensi Hasil Data Konsentrasi

Mahasiswa Jurusan Pendidikan Olahraga

\begin{tabular}{ccc}
\hline Kelas Interval & Frekuensi Absolut & Frekuensi Relatif \\
\hline $31-36$ & 1 & 2,5 \\
\hline $25-30$ & 6 & 15 \\
\hline $19-24$ & 11 & 27,5 \\
\hline $13-18$ & 20 & 50 \\
\hline$\leq 12$ & 2 & 5 \\
\hline Jumlah & 40 & 100 \\
\hline & bolavoli dasar & mahasiswa Jurusan
\end{tabular}

Data konsentrasi dari 40 orang mahasiswa Jurusan Pendidikan Olahraga Fakultas IImu Keolahragaan UNP, didapatkan skor tertinggi 36 dan skor terendah 11, range (jarak pengukuran) 25. Distribusi skor menghasilkan rata-rata hitung (mean) 19,25, nilai tengah (median) 23,5 dan simpangan baku (standar deviasi) 5,51

Motivasi belajar merupakan kondisi-kondisi atau keadaan yang mengaktifkan

atau memberi dorongan kepada seseorang untuk bertingkah laku dalam mencapai tujuan yang ditimbulkan oleh motivasi tersebut. Motivasi mahasiswa sangat penting dalam belajar keterampilan bolavoli dasar dalam proses tatap muka perkuliahan, dan dalam penelitian ini hasil yang ditemukan terbukti bahwa motivasi belajar mempunyai hubungan secara signifikan dengan keterampilan bolavoli dasar mahasiswa Jurusan Pendidikan Olahraga FIK UNP, dan diterima kebenaran secara empiris, serta motivasi belajar berkontribusi sebesar 12,39\% terhadap keterampilan bolavoli dasar mahasiswa.

Konsentrasi dan motivasi belajar merupakan dua faktor yang dapat menunjang kesuksesan dalam mencapai hasil belajar keterampilan
Pendidikan Olahraga FIK UNP. Hasil penelitian menyatakan terdapat hubungan yang signifikan konsentrasi dan motivasi belajar secara bersamasama dengan keterampilan bolavoli dasar mahasiswa Jurusan Pendidikan Olahraga FIK UNP, dan diterima kebenaran secara empiris, serta motivasi belajar berkontribusi sebesar $25,50 \%$ terhadap keterampilan bolavoli dasar mahasiswa. Oleh karena itu konsentrasi dan motivasi belajar mahasiswa perlu ditingkatkan agar keterampilan bolavoli dasar mahasiswa meningkat menjadi lebih baik.

Berdasarkan di atas, maka jelaslah bahwa dari 40 orang mahasiswa Jurusan Pendidikan Olahraga Fakultas IImu Keolahragaan Universitas Negeri Padang, yang memiliki konsentrasi untuk kelas interval $\leq 12$ adalah 2 orang (5\%), kelas interval $13-18$ yaitu ada 20 orang (50\%) dan yang memiliki kelas interval 19 - 24 yaitu sebanyak 11 orang $(27,5 \%)$. Sedangkan untuk kelas interval $25-30$ adalah 6 orang (15\%) dan kelas interval 31 - 36 yaitu hanya 1 orang $(2,5 \%)$. Untuk lebih jelasnya variabel konsentrasi mahasiswa Jurusan Pendidikan Olahraga Fakultas IImu Keolahragaan Universitas Negeri Padang tersebut dapat dilihat histogram pada gambar berikut ini: 


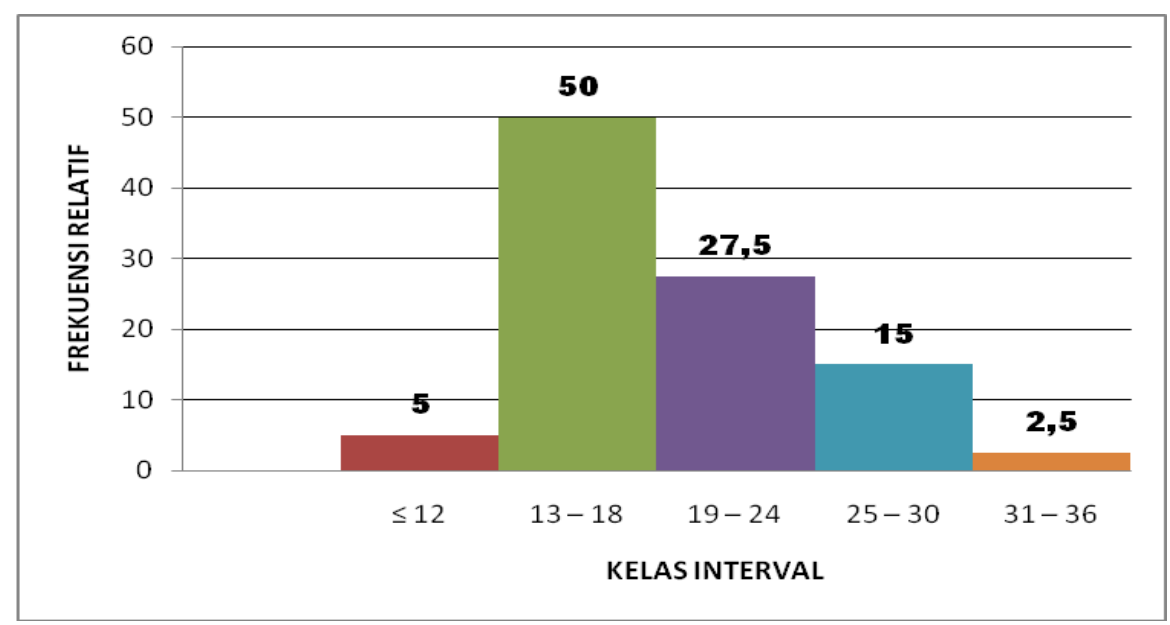

Histogram Frekuensi Hasil Data Konsentrasi Mahasiswa Jurusan Pendidikan Olahraga

Dari hasil data yang telah Keolahragaan Universitas Negeri dikemukakan di atas, maka dapat Padang, didapatkan skor tertinggi 119 disimpulkan bahwa sebanyak 15 orang dan skor terendah 85, sedangkan $(37,5 \%) \quad$ mahasiswa memiliki range (jarak pengukuran) 34. Distribusi konsentrasi dengan skor di atas skor kelompok rata-rata, dan 3 orang $(7,5 \%)$ mahasiswa $\mathrm{g}$ memiliki skor dalam kelompok rata-rata. Sedangkan mahasiswa yang memiliki skor konsentrasi untuk di bawah skor kelompok rata-rata ada sebanyak 22 orang (55\%).

Motivasi Belajar

Data variabel motivasi belajar dari 40 orang mahasiswa Jurusan Pendidikan Olahraga Fakultas IImu skor menghasilkan nilai rata-rata hitung (mean) 102,73 dan nilai tengah (median) 102, serta simpangan baku (standar deviasi) sebesar 8,18. Distribusi frekuensi hasil data motivasi belajar mahasiswa Jurusan Pendidikan Olahraga Fakultas IImu Keolahragaan Universitas Negeri Padang dapat dilihat tabel.

Distribusi Frekuensi Hasil Data Motivasi belajar Mahasiswa Jurusan Pendidikan Olahraga

\begin{tabular}{ccc}
\hline Kelas Interval & Frekuensi absolut & Frekuensi relatif \\
\hline $113-119$ & 3 & 7,5 \\
\hline $106-112$ & 12 & 30 \\
\hline $99-105$ & 15 & 37,5 \\
\hline $92-98$ & 5 & 12,5 \\
\hline $85-91$ & 5 & 12,5 \\
\hline Jumlah & 40 & 100 \\
\hline & orang mahasiswa Jurusan Pendidikan
\end{tabular}

Berpedoman pada Tabel 4 di atas, Olahraga Fakultas IImu Keolahragaan dapat disimpulkan bahwa dari 40 Universitas Negeri Padang untuk 
variabel motivasi belajar, yang memiliki kelas interval 85 - 91 ada 5 orang $(12,5 \%)$, kelas interval 92 - 98 juga ditemukan 5 orang $(12,5 \%)$ dan kelas interval 99 - 105 adalah 15 orang $(37,5 \%)$. Kemudian yang memiliki kelas interval 106 - 112 adalah 12 orang (30\%) dan yang memiliki kelas interval 113 - 119 yaitu ada 3 orang (7,5\%). Untuk histogram variabel motivasi belajar mahasiswa pendidikan olahraga tersebut, dapat dilihat pada gambar 4 .

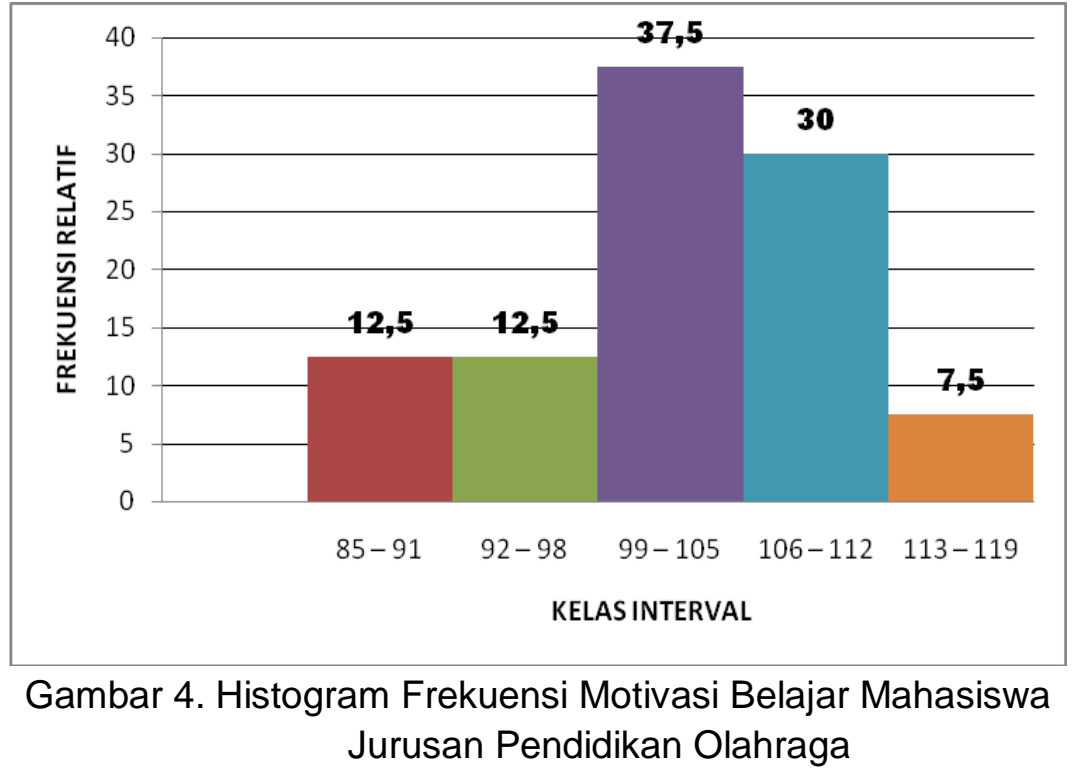

Berdasarkan hasil data yang telah dikemukakan di halaman sebelumnya, maka dapat disimpulkan bahwa dari 40 orang mahasiswa Jurusan Pendidikan Olahraga FIK UNP, yang memiliki motivasi belajar dengan skor di atas kelompok rata-rata adalah sebanyak 22 orang $(55 \%)$ dan skor dalam kelompok rata-rata yaitu ada 2 orang (5\%). Sedangkan mahasiswa yang memiliki skor motivasi belajar yang berada di bawah skor kelompok ratarata adalah sebanyak 16 orang (40\%). Keterampilan Bolavoli Dasar

Data keterampilan bolavoli dasar dari 40 orang mahasiswa Jurusan Pendidikan Olahraga Fakultas IImu Keolahragaan Universitas Negeri
Padang, didapatkan skor tertinggi adalah 62,96 dan skor terendah 35,64. Sedangkan range (jarak pengukuran) adalah 27,32. Selanjutnya distribusi skor menghasilkan nilai rata-rata hitung (mean) 50,00 dan nilai tengah (median) 49,3. Sedangkan simpangan baku (standar deviasi) adalah 6,71. Distribusi frekuensi hasil data keterampilan bolavoli dasar mahasiswa Jurusan Pendidikan Olahraga Fakultas IImu Keolahragaan Universitas Negeri Padang dapat dilihat pada tabel. 
Distribusi Hasil Data Keterampilan Bolavoli Dasar Mahasiswa Jurusan Pendidikan Olahraga

\begin{tabular}{ccc}
\hline Kelas Interval & Frekuensi Absolut & Frekuensi Relatif \\
\hline $57,50-62,96$ & 8 & 20 \\
\hline $52,03-57,49$ & 9 & 22,50 \\
\hline $46,56-52,02$ & 10 & 25 \\
\hline $41,09-46,55$ & 10 & 25 \\
\hline $35,62-41,08$ & 3 & 7,5 \\
\hline Jumlah & 40 & 100 \\
\hline
\end{tabular}

Berdasarkan pada Tabel di atas, maka dapat disimpulkan bahwa dari 40 orang mahasiswa Jurusan Pendidikan Olahraga Fakultas IImu Keolahragaan Universitas Negeri Padang, yang memiliki kelas interval 35,62 - 41,08 adalah 3 orang $(7,5 \%)$, untuk kelas interval 41,09 - 46,55 adalah sebanyak 10 orang $(25 \%)$ dan kelas interval
46,56 - 52,02 juga sebanyak 10 orang (25\%). Sedangkan yang memiliki kelas interval 52,03 - 57,49 yaitu 9 orang $(22,50 \%)$ dan untuk kelas interval 57,50 - 62,96 yaitu 8 orang (20\%). Untuk histogram variabel keterampilan bolavoli dasar mahasiswa tersebut, dapat dilihat pada gambar.

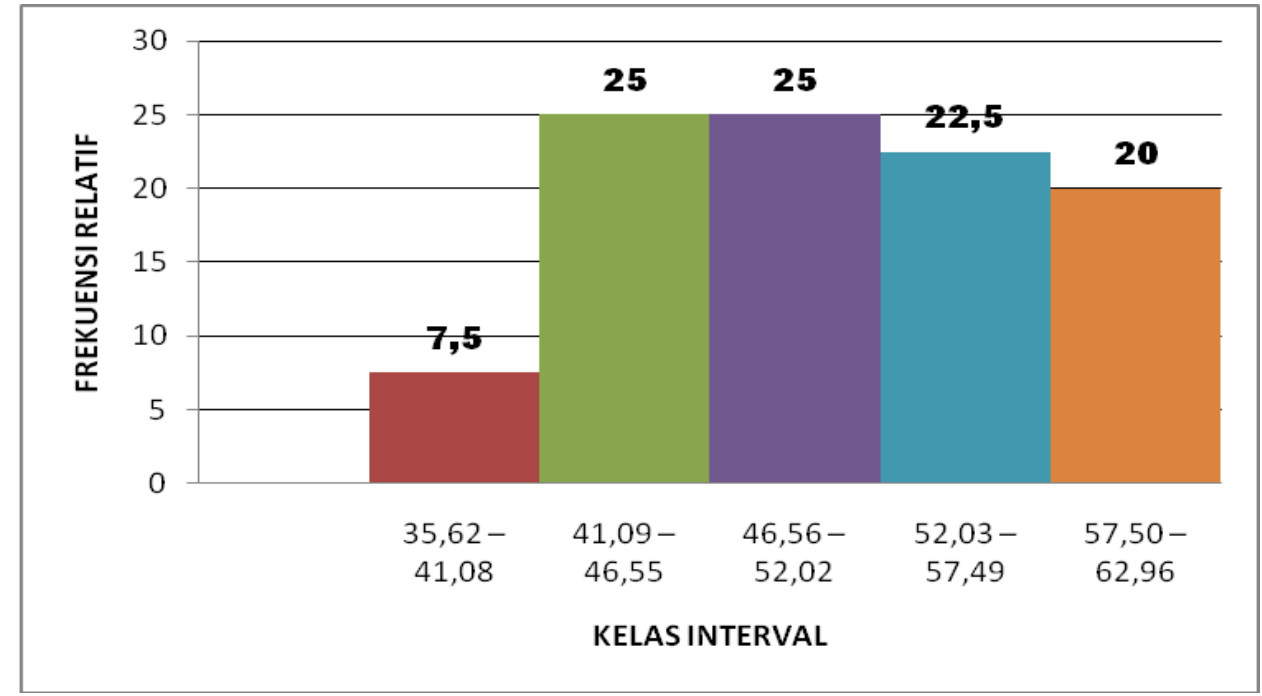

Histogram Frekuensi Keterampilan Bolavoli Dasar

Berdasarkan hasil data tentang variabel keterampilan bolavoli dasar mahasiswa Jurusan Pendidikan Olahraga Fakultas IImu Keolahragaan Universitas Negeri Padang yang telah dikemukakan di atas, maka dapat disimpulkan bahwa yang memiliki keterampilan bolavoli dasar dengan skor di atas kelompok rata-rata berjumlah sebanyak 17 orang $(42,50 \%)$ dan yang berada dalam skor kelompok rata-rata tidak ada satu orangpun yang memilikinya. Sedangkan untuk di bawah skor kelompok rata-rata ada sebanyak 23 orang $(57,50 \%)$. 


\section{KESIMPULAN}

Kesimpulan penelitian ini: 1) Konsentrasi mempunyai hubungan yang signifikan (berarti) dengan keterampilan bolavoli dasar mahasiswa Jurusan Pendidikan Olahraga Fakultas IImu Keolahragaan Universitas Negeri Padang, dengan ditemui $t_{\text {hitung }}=2,95>t_{\text {tabel }} 1,69$, dan memberikan kontribusi sebesar $18,66 \%$, sertaditerima kebenarannya secara empiris,. Artinya semakin tinggi konsentrasi mahasiswa, maka semakin baik keterampilan bolavoli dasar. 2) Motivasi belajar mempunyai hubungan yang signifikan (berarti dengan keterampilan bolavoli dasar mahasiswa Jurusan Pendidikan Olahraga Fakultas IImu Keolahragaan Universitas Negeri Padang, dengan ditemui $t_{\text {hitung }}=2,32>t_{\text {tabel }} 1,69$, dan memberikan kontribusi sebesar sebesar 12,39\%, serta diterima kebenarannya secara empiris. Artinya semakin tinggi motivasi belajar mahasiswa, maka semakin tinggi keterampilan bolavoli dasar mereka.3) Konsentrasi dan motivasi belajar secara bersama-sama mempunyai hubungan yang signifikan (berarti) dengan keterampilan bolavoli dasar mahasiswa Jurusan Pendidikan Olahraga Fakultas IImu Keolahragaan, dengan ditemui $F_{\text {hitung }}=6,33>F_{\text {tabel }}$ 3,255 , dan memberikan kontribusi sebesar 25,50\%, serta diterima kebenarannya secara empiris. Artinya semakin tinggi konsentrasi dan motivasi belajar mahasiswa dalam perkuliahan bolavoli dasar, maka semaikin tinggi pula keterampilan bolavoli dasar yang dimiliki mahasiswa.

\section{DAFTAR RUJUKAN}

Bachtiar. 1999. Pengetahuan DasarDasar Permainan Bolavoli. Padang: FIK UNP.

Dimyati. 2006. Belajar dan
Pembelajaran. Jakarta
Departemen Pendidikan dan
Kebudayaan, dan Rineka Cipta.

Erianti. 2011. Buku Ajar Bolavoli. Padang: Fakultas IImu Keolahragaan. Universitas Negeri Padang.

Komarudin. 2013. Psikolgi Olahraga. Bandung: PT Remaja Rosdakarya offset.

Mudjiono. 2006. Belajar dan Pembelajaran. Jakarta : Departemen Pendidikan dan Kebudayaan, dan Rineka Cipta.

Nuril Ahmadi. (2007). Pendidikan

Olahraga Bola Voli. Solo: Era

Pustaka Utama.

Prayitno, 1989. Motivasi Belajar. Jakarta P2LPTK.

Riduwan, 2004. Belajar Mudah Penelitian Untuk Guru, Karyawan, dan Peneliti Pemula. Bandung: Alfabeta.

Roji. 2007. Pendidikan Jasmani, Olahraga dan Kesehatan. Jakarta: Erlangga.

Sardiman A.M. 2001. Interaksi dan Motivasi Belajar Mengajar.PT. Rajagrafindo Persada, Jakarta.

Setyobroto, 2001. Psikologi Olahraga. Jakarta: Percetakan Universitas Negeri Jakarta. 
Yunus.1992. Olahraga Pilihan Bolavoli, Jakarta: P2Tk, Dirjen Dikti, Depdikbud.
Sugiyono. 2009. Metode Penelitian Pendidikan, Pendekatan Kuantitatif, Kualitatif. Bandung: Alfabeta. 